period. For the whole experimental period the daily mean gains were $637-638$ and $627 \mathrm{~g}$, the feed conversion ratio $3.36-3.34$ and $3.4 \mathrm{I}$ for the control group, group 2 (I 5 p. Ioo cassava) and group 3 ( 30 p. Ioo cassava), respectively.

No significant difference was observed between the three treatments either over the whole period or over the growing and finishing periods separately.

Carcass quality was the same for dressing out percentage, but rather in favour of cassava groups for backfat thickness. This advantage can be explained by the higher lysine content of the latter.

In the second trial, Io8 animals between 30 and roo $\mathrm{kg}$ live weight, were subjected to the same experimental conditions as in the first trial in order to compare three diets: barley-soybean control diet (group I), 30 p. I oo cassava (group 2), 40 p. Ioo cassava (group 3), i.e. 36 pigs per treatment.

Growth and feed conversion ratios were rather close to those recorded during the ist trial: 66o-650-635 g; and a feed conversion ratio of 3.33-3.37 and 3.44 for groups $\mathrm{I}, 2$, 3, respectively. No significant difference was observed either on the whole period or on the growing finishing period, carcass quality was absolutely the same for the three diets.

In conclusion, these two trials concerning substitution of poor quality cassava for barley allowed to obtain the same growth and carcass quality performance in bacon pigs of $3^{\circ}$ to I $00 \mathrm{~kg}$ whatever the incorporation level of cassava. Thus, the prediction equation of the cassava energy value from its chemical composition, stated by PEREZ (I.N.R.A., I979) was verified in these two trials.

\title{
Energy evaluation of barley for pigs. Prediction from analyses of fibre content
}

\author{
J. M. PEREZ, Brigitte RAMOELINTSALAMA, D. BOURDON \\ I.N.R.A., Station de Recherches sur l'Élevage des Porcs \\ 78350 Jouy-cn-Josas (France)
}

In order to define more accurately the influence of changes in the composition of barleys on their energy value, a digestibility experiment was made on 28 castrated male pigs with a mean weight of $30 \mathrm{~kg}$. The animals, kept in metabolism crates, were subjected to a ro-day faeces and urine total collection period and received only cereals diets. Seven types of barley, of different morphology and composition were studied: two six-row winter barleys (Astrix and Sympa), two two-row winter barleys (Alpha and Sonja), one spring barley (Aramir) and two naked barleys (CF I I 3, Nudinka) containing 6.6-6.I-5.5-4.7-4.5-2.4 and 2.2 p. I oo respectively of Weende crude fibre in the dry matter.

A decrease in the digestibility of the dietary components was observed in relation with the hull percentage of the seeds leading to a Io-point difference in the apparent digestibility coefficients of dry matter, organic matter and energy, between the extreme barleys.

Increase in the crude fibre contents led to a highly significant linear decrease $(P<0.0 r)$ in the apparent digestibility coefficient of energy, corresponding to a -2.27 point reduction of the A.D.E. per supplementary point of crude fibre in the dry matter (D.M.)

A.D.E. $=91.99-2.27$ crude fibre p. Ioo D.M. $\quad r=-0.965^{* *}$

The same was observed with increasing Acid Detergent Fibre (A.D.F.) contents and Neutral Detergent Fibre (N.D.F.) contents:
A.D.E. $=90.43-\mathrm{r} .69$ A.D.F. p. Ioo D.M.$$
r=-0.96 \mathrm{I} * *
$$$$
\text { A.D.E. }=98 . \mathrm{II}-\mathrm{I} .04 \text { N.D.F. p. Ioo D.M. } \quad r=-0.88 \mathrm{I} *
$$

The directly measured digestible energy values (Kcal/kg D.M.) were: 3377 (Astrix), 3448 (Sympa), 3366 (Alpha), 3580 (Sonja), 3563 (Aramir) for the hulled barleys and 3784 (C.F.II3) and 3867 (Nudinka), respectively, for the naked barleys, i.e. values comparable to that of wheat. Therefore the crude fibre content seems to be the main factor of variation in the energy value of barley for the pig since in the present study it accounts for $93 \mathrm{p}$. Ioo of the variation in the digestible energy value.

On the basis of the results obtained it is possible to predict the digestible energy value of 
a type of barley from its crude fibre content using a correction of I r K Kcal per supplementary point of crude fibre in the seed dry matter :

D.E. (Kcal $/ \mathrm{kg}$ D.M.) $=4.072$ - I I o crude fibre p. I00 D.M. $r=-0.96 \mathrm{I}^{* *}$

A prediction equation of the energy value of barley from their bulk weight is also suggested and discussed.

\title{
Influence of the type of barley (two-row; six row) on the performances of weaned piglets
}

\author{
J. B. BOUARD, J. FEKETL, M. LEUILLEF \\ Institut Technique des Céréales et des liourrages \\ 8, avenue du Président-Wilson, 75116 Paris
}

In a trial including 396 piglets weaned at 26 days large amounts of barley of two different types (SONJA: two-row winter barley, ASTRIX: six-row winter barley) and of different crude fibre contents ( 4.8 and 6.4 p. roo dry matter) were incorporated into the diets from 38 days of age and during 4 weeks. We applied to both types of barley the prediction equation of digestible energy established by PEREZ at al. (I980) in growing pigs. The difference in the energy value between both types was $5 \mathrm{p}$. I00; it was only $3.6 \mathrm{p}$. I 0 o between experimental diets rebalanced with protein.

'Two protein levels ( 18 and 22 p. IOo) were used for comparing the two types of barley. The response of the animals to the protein content was spectacular: for the same amount of feed ingested the growth and feed conversion ratio were improved by almost to p. Ioo. This suggests that in this protein range piglets react strongly and favourable provided that the herd management (breeding and health factors, environment) is satisfactory. Therefore, the comparison of different cereals for piglet diets requires use of the same protein level. This reduces the value of studies based on the quantitative substitution of cereals.

The same response was obtained in a previous study (BOUARD $e t$ al., 1979) where the compared protein levels were 18 and $20 \mathrm{p}$. I 00 . It seems to be a response to lysine rather than to the protein level, as confirmed by trials made in piglets with wheat or maize as only cereal. (BOUARD and IFKETK, I 978). The response of piglets to the decrease in the dietary energy level was an increase in the feed intake the relative value of which ( $3.9 \mathrm{p}$. I oo) was close to the theoretical energy difference ( 3.7 p.roo ). This kind of response well known in bacon pigs fed ad libitum was seldom noticed in piglets. However, it was demonstrated that when increasing the energy density of the diet by addition of fat the feed intake decreased in weaned piglets (O'GRADY and BOWI,AND, 1972; O'GRADY, 1978 ). The increased feed intake compensating for the lower energy value of six-row barley led to the same growth rate than two-row winter barley ( $54^{8} \mathrm{~g}$ a day).

These results suggest that as far as barley is concerned, feeding of weaned piglets may be similar to that of bacon pigs.

Hence, the prediction equations of the barley energy values established in growing pigs and based on Weende crude fibre content should be transposed to the younger animal from $8 / \mathrm{To} \mathrm{kg}$. 